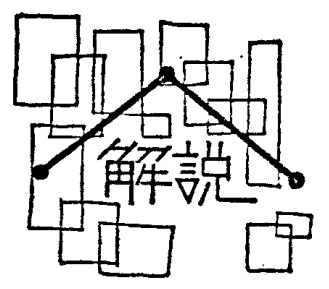

\title{
SCARA ロボットの設計思想
}

\author{
牧 Hiroshi MAKINO $_{\text {野 }}$ 洋*
}

\begin{abstract}
Key Words: Design Engineering, Design Philosophy, Mechanism, Robot, SCARA, Automatic Assembly
\end{abstract}

\section{1. 緒言}

スカラロボットは筆者が開発したロボットであ るが，それまでの他のロボットがおおむね (1) 器 用である，(2) 遅い，(3) 柔らかいというイメージを 持つのに対して，スカラロボットは, (1) がっちり している, (2) 早い, (3) 正確であるというイメージ を持つ.

どうしてそのようなロボットができたのかと言 えば，それはその根本にある設計思想が従来のも のとは異なっていたからである.ここではその思 想について説明し，それを実現するための設計の 筋道について述べることにする.この筋道は筆者 にとっては一本道の思考過程と，それを裹付ける ための実験の繰返しであり，決して単なる思い付 きでこのような形にしたというむのではなかった のである.

\section{2. スカラ以前の思考過程}

多種少量生産における自動組立をいかなる機械 装置によって効果的に行いうるかということは長 年にわたっての大きな課題であった.

当初，はん用化の方向と高速化の方向之はま。 たく相反するように思われた(1). はん用性を称ら えば㸚らうほど高速性が失われ，したがって生産 工程に䓴入することができないというジレンマに 楩っていた.

しかし，そのはん用性 (versatility) という言 葉で要求されているものの内容を分析してみる と, 器用さ (dexterity) と融通性 (flexibilty) の 二っに分けられることがわかった. 前者は動作の

* 正員, 山梨大学工学部 (两 400 甲府市武田 4-3-11).
自由度が多くいろいろな作業に対応できること， 後者はモデルチェンジに対応して速やかに作業プ ログラムを変更できることをいう，そうして，仕 事の性質によっては，たとえ多種少量生産と言え ども, 器用さは必要でなく融通性のみが要求され る場合があり，そのとき高生産性 (productivity) は失われてはならない。この両者の性質を合わせ 持った「PF マシン(2)」を作れば，これは多種少 量生産の実現のために要求されていた空白をかな りの程度に埋めることができるであるうと思われ た.

他の分野に学ぶならば, それはロボットではな くて NC (数值制御) である. マシニングセンタ にならってNCアセンブリセンタ(3)を作るなら ば，それは必ずや多種少量生産の自動組立にとっ て有効なものとなりうるに違いない.こうして, NC アセンブリセンタの試作機による実験が始ま った.

\section{3. はめあい問題}

組立作業の本質ははめあいにある. 大なり小な りのクリアランスを持っ二つの部品の相対位置決 めを行うことがすなわち組立なのであり，したが がって, 軸穴挿入問題 (peg-and-hole problem) は組立の実験として重要な意義を持つ.

すでに日立製作所はカフィードバックカ方式によ るはめあいロボット(4)を完成させており, Draper 研究所の Whitney 教授らはコンプライアンスの 有用性に気付き, $\mathrm{RCC}^{(5)}$ と呼ばれる装置を完成さ せようとしていた.

しかし筆者は別の解決法を考えていた，それが 「選択的柔㳄性 (selective compliance)」と後に 名付けた方法である。 
洋

\section{4。選択的柔軟性}

図1亿選択的コンプライアンスの効果を示寸。 唓と穴の位置がずれ，軸が公の面取部に当たった とする。このとき，軸部品を保持しているロボッ トのコンプライアンスには二通りのものがあり， それぞれの効果汁異なっている。亦な゙橫ずれコン プライアンスであるが，この存在に上って位置ず れは修正され，はめあいが可能になる。これに效 し朝倒れコンプライアンスが存在すると軸仙候 き，クリアランスの小さい場合には穴の浅い位置 で二点接触が起こり，その結果，こじれによって それ以上の挿入ができなくなる。したがって，㮛 ずれコンプライアンスが大きく，軸倒れコンプラ イアンスが小さいような機構が望ましく，これを 選択的柔㳄性と名付讨る。

このような性質は屏風形構造をとることによっ て実現できる。屏風は上下方向に対する䟝性が高 く，横方向には変形しや寸い(コンプライアンス が大きい）のである. 二次元の位置決め在行うた めに屏風の板の数を 2 枚とし， 2 枚の板がほほ值

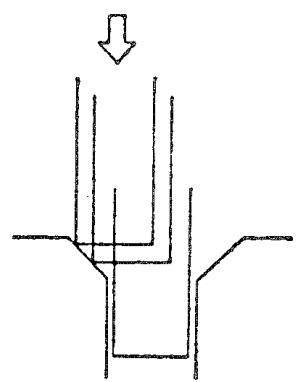

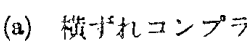
イアンス

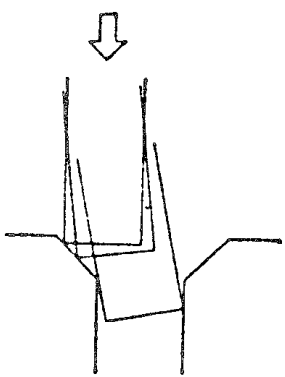

(b) 柚倒れコンプラ イアンス
困１選択的コンプライアンスの效果

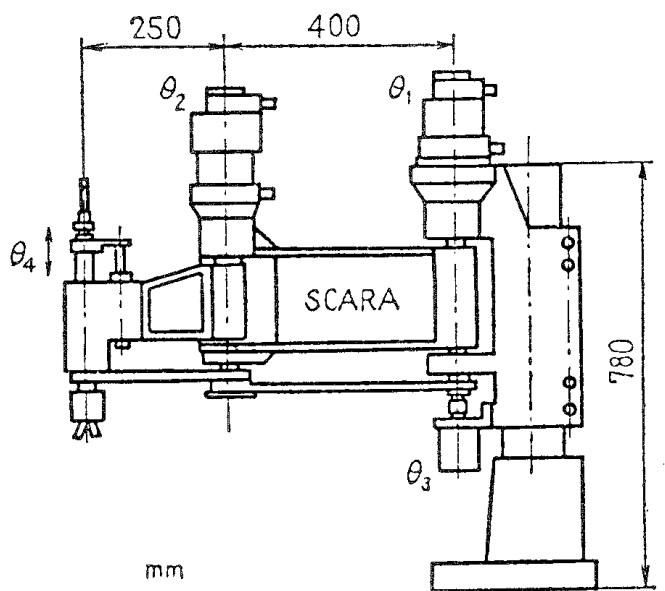

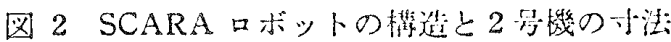

角に近いような状態で使用すれば水平二方向への コンプライアンスを保証できる.

こうして SCARA, 寸なわち, Selective Compliance Assembly Robot Arm（選规的柔軟性を 持った組立用のロボットの手）が誕生することに なった。

このロボットの開発は「SCARA 研究会」とい う名の研究コンソーシアムの援助のもとに行われ たが，その開発の释過な上゙は他の文献（6）にゅず りここではこのロボットの詆㖕の過程について 述べることにしたい。

\section{SCARA の自由度構成}

図 2 亿 SCARA ロボットの構造を示寸. $\theta_{1}$ で示 した「凧の」モータによりアーム 1 を摇動させ,そ の先に取り付けられた「郝の」モータ $\theta_{2}$ により アーム 2 を摇動させる.この 2 軸により工具点の 平面的な位置決めを行う。別のモータ $\theta_{3}$ は $1: 1$ のタイミングベルト 2 本を通じて工具軸を回転さ せるようになっており，觕軸挿入の場合などにお ける部品の姿勢決めを行う。この部分の機構はち ようど製図器のようになっており， $\theta_{3}$ に大力が与 えられないときには姿勢保持の役割を果たす。

別に工具韩の上下 $\theta_{4}$ があり，この駡動にはエ アシリンダを用いている. ボア径 $\phi 25$ のシリン ダを用いるとき, $6 \mathrm{kgf} / \mathrm{cm}^{2}$ 程度の通常のエア圧 で $25 \mathrm{kgf}$ 程度の推力を得ることができる.

以上述べたごとく, SCARA は 4 自由度のロボ ットであるが，これ法平面位置決め形ロボット (2 $1 / 2$ 空開作動形ロボット) として十分な自由塺 を持っている。

すなわち、ロボットは通常 6 自由度在必要とす ると言われるが，これは等關的なハンドリングを 想定するからなのであって，その埸合には位置決 めの自由度 3 ，姿勢決如の自由度 3 の合計 6 を必 要とするのである。しかし，平面的なハンドリン グでは位翼決めの自由度 2 , 姿势決めの自由度 1 の合汁 3 で十分なのであり, SCARA の場合は, これに，装入動作のための自由度 1 (位置決め平 面に淔交する方向）を加えているのである、皘み 菲极權造を持った組立品の場合にはこのような口 ボットで十分に組立を行うことができ，奏際のラ インで検垨した結果でも 70〜80\% はこの動作で 十分であるとの結論を得ている。 
スカラ形は通常「水平多関節形」と呼ばれてい るが，これは「平面多関節形」と呼ぶ注うが正確 であると思われる，その意味は平面的な位置決め を 2 自由度の多関節形座標系によって行うという ことである。

表 1 には平面位置決めロボットの 3 形式を示し た. 表において l は值動, $\theta$ は回転関節を示し, 添字洨ロボットのベースに近い側から順番に打っ ている，「装入」というのは精機学会自動組立専 門委員会で制定した用語(7)であって，捙入，はめ 合わせ，のせなどの作業を総称していう言葉であ る.

SCARA ロボットは単なるハンドリング（=位。 置決め十姿势決め) だけを行うので沈なく，「装 入」という仕事を行うように設計されたものであ る.そのため，機械全体の構造は十分に装入力に 耐えうるようになっているのであり，これがこの ロボットに力強さ，たくましさという印象を与え るもととなっていると思われる.

多くの人はこの装入軸を位置決め軸の一つであ るかのように誤解しており，したがってサーボュ ントロールが必要だと考えている。そうではない のであって，装入軸の場合には位置制御よりもむ しろ装入力制御の方が重要なのである.だからエ アシリンダを用いているのである.

\section{6. 作業域とアーム長さの決定}

2 関節形ロボットのアーム舆さを $R_{1} \mathrm{~mm}$ およ び $R_{2} \mathrm{~mm}$ とするとき，作業域として $R_{1} \times R_{2}$ $\mathrm{mm}^{2}$ の長方形の面積を十分カバーすることがで

表 1 平西位羁決め口ボットの分類

\begin{tabular}{|c|c|c|c|c|c|}
\hline 形 & 式 & 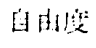 & 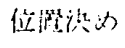 & 姿放決和 & 装人 \\
\hline \multicolumn{2}{|c|}{ 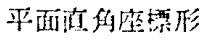 } & 4 & $l_{1} \quad l_{2}$ & $\theta_{3}$ & $l_{4}$ \\
\hline \multicolumn{2}{|c|}{ 平面椣座锤形 } & 4 & $\theta_{1} \quad l_{2}$ & $\theta_{3}$ & $l_{4}$ \\
\hline \multicolumn{2}{|c|}{ 平酒多阙筑形 } & 4 & $\theta_{1} \quad \theta_{2}$ & $\theta_{3}$ & $l_{1}$ \\
\hline
\end{tabular}

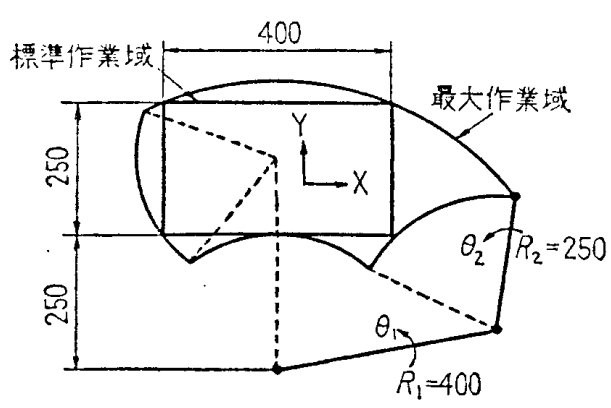

図 3 SCARA ロボットの作菜域
き，これを標準作業域と呼ぶことする（図 3）. これから逆にロボットのアーム長さを決定するこ とができる. すなわち， $R_{1} \times R_{2}$ の作業域が必要な とき，アーム長を $R_{1}, R_{2}$ と寸ればよい. SCARA 試作 2 号機の場合, M3〜M5 のねじ締めを主な目 的として設計されたが，このようなねしを使用す る製品はテレビ，カセットレコーダ，カーラジオ など電気製品に多く, ワークの大きさは $300 \times$ $300 \mathrm{~mm}^{2}$ 以内にほぼ入る。したがって $R_{1}=300$, $R_{2}=300$ とすればよいが, ここで，機械の構造上 $R_{1}>R_{2}$ にしたかったので, $R_{1}: R_{2}=1.6: 1$ の比 をとり， $R_{1}=400, R_{2}=250$ とした. $1: 1.6$ の比 は黄金分割 ${ }^{(8)} 1: 1.612 \cdots に$ にわめて近く，標準 数 $R 5$ はこの比となっている.

作ってみての結果から判断すると，この比を採 用するときアームのバランスはきわめて良く，子 ところも広いので機械の据付けが容易であるとい う利点がある。

\section{7. アームの運動制御}

コンベヤ上をパレットが流れ，そのパレットの 大きさが標準作業域に等しいと仮定する、コンべ ヤの外側（両侧のいずれか片方または両方）に部 品供給装㯰があり，その端点（装入待機位置）は 標準作業域の外側ではあるが最大作栄域の内部に 入っているとする. ロボットはここから部品をつ まみ上げてパレット上のワークに装入する. 図 4 はそのような作業配置の実例を示している(9).

さて，上述のようなつまみ装入 (pick-and-

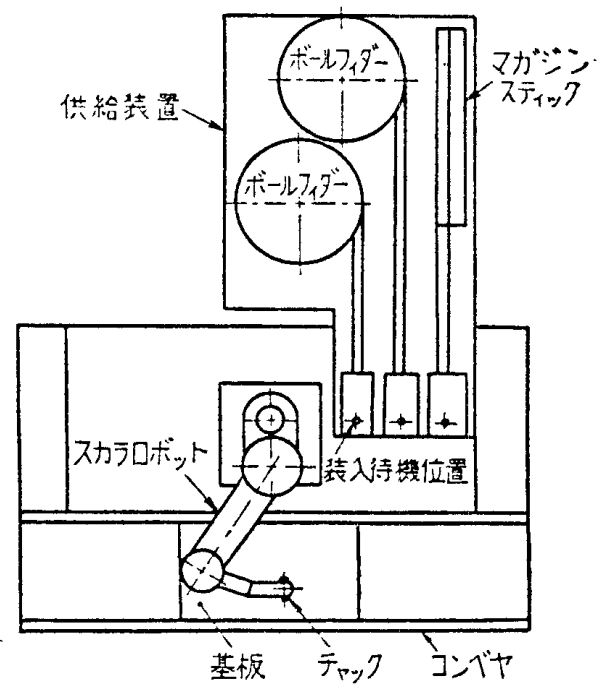

図 4 SCARA ロボットによるプリント 苦板組立ラインの棈成 
place）作業吉例にとると、ロボットの片道のス トローク注 200 300 mm 注必要である。一方基 給部品の重さ汶一般に沈 $0.5 \mathrm{kgf}$ 以下であるう が，中に㳉重いものも亦る。ロボットの踠の先化 付く作業工具汶軽いものでも $3 \mathrm{kgf}$ ，中に沬 10

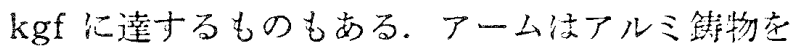
用いるなどしてなるべく柽く作るが，それでも先 端の集中質量に換算して 2 3 kgf になることは 避けら机ない。

以上をまとめて言うと，西いものを铛いアーム の先に付行て，長い距離を振りまわし，しかもこ の動作老片道 $0.5 \mathrm{~s}$ というような短い時間の間に 行いたいということである。そうやって動かし て，残留振動やオーバシュートが出ないようにす るにはどうしたら良いか。

これはカム征線の問題である。運動の始点から 終点までの間にアームにどのような（觕）速度。 （角）加速度在上えるべきかという閶題なので市

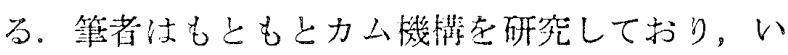
くつかの力ム曲線(10)老設䛅した経験を持ってい るので,この目的に沿う曲線の望ましい形につい てはほぼ想像がつく。こうして設計したのが $\mathrm{NC} 1 ， \mathrm{NC} 2$ の両曲線である(図 5 参照)。婳曲線 は $T_{3}$ の值が罢なるだけで，形としては同じでめ る。実虽の結果 NC2 曲線の方が良かったので， 以後 NC2 標淮として採用することにした。

NC2 曲線注トラペクロイド(11)采の曲線であっ て，加速域に效して減速域を長く（NC2の埸合は 2 倍に) とりながら，最大速底 $V_{m}$ や正の最大 加速度 $A_{\text {inp }}$ の做があ交り大きくならないように 工头されている。始点を除いて加速度は連続であ

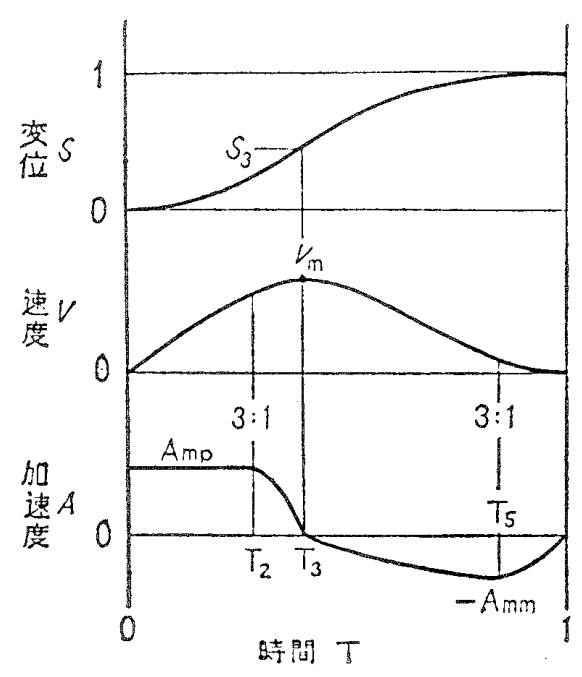

图 $5 \mathrm{NC} 1, \mathrm{NC} 2$ 曲線
り，その変化率 (躍動) の值も小さい，通常の NCに用いられている台形速度，三角速度曲線は 加速度が不連続であり，商速において振動を生ず る原因となる。公屋が 30 年も前に放渠した曲 線を制御屋はなぜいまだに使っているのか。

なお， NC2 曲線にお汸る立上がり部分の加速度 の不連続は「政り出し」効果を放らったものであ り，これがサーボ機構に対する入力であって，出 カが必ずしもこれに追蹃しないことを考慮してい る.

さて，このようなカム曲線による運動を与える のに，ストロークやタイミングが一定であればカ ムを用いれば良いのであるが，フレキシビリティ を要するロボットにおいて注カムそのものは使用 できない。そこで，DC サーボモータを用い，そ のモータの回転数を図の速度曲線儿従って变化さ せることにした。

マイクロコンピュータが出現したおかげでこの ようなことが比較的容易にできるようになった。 カム曲線をデータとしてマイコンに記憶してお き，それにもとづいて加減速制御されたパルスを 作って，ディジタルサーボ機構に送り込んでやれ ばよいのである. マイコンとしては試作 1 号機 (53 年 10 月完成) では 8080，2号機（55 年 5 月 笔成）では Z 80 を用いた CPUを使用した。

制御システムの概略を図 6 亿示す。アーム回転 を年える $\theta_{1}, \theta_{2}$ のモータにはプリントモータを用

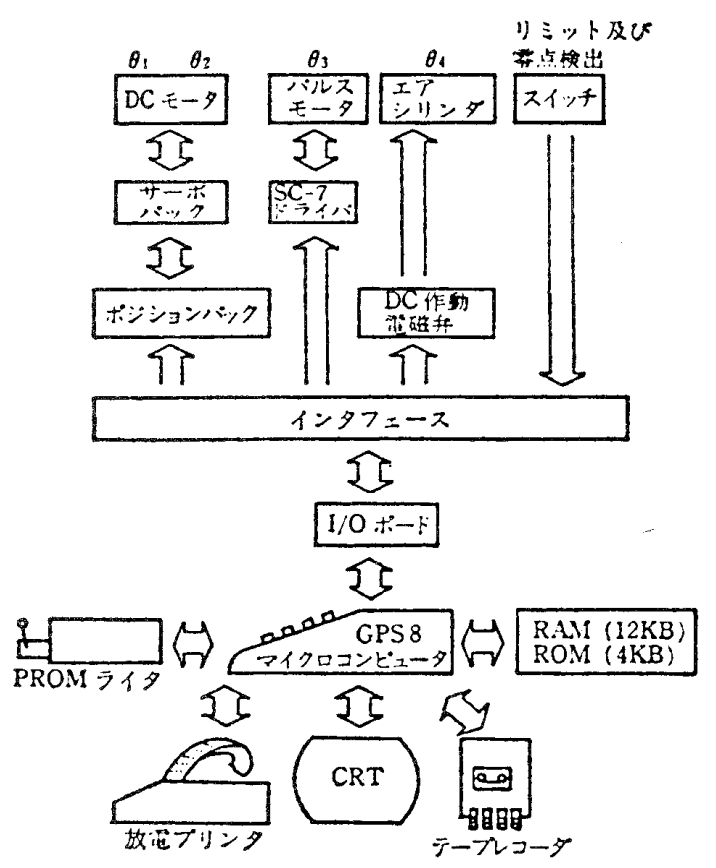

図 6 SCARA ロボットの制御システム 
い，サーボ系としてメーカから供給されている 「サーボパック」(速度制御ユニット)および「ポ ジションパック」（D-A 変換ユニット）をその まま利用した. ポジションパックにパルス列を入 力すると,モータの回転角はパルス数に, 回転角速 度はパルス列の周波数に比例するように制御でき る.これを利用して，図７に示すSテーブル法で パルス列を作って制御する. 図 7 は 41 ループ回 数の間に 23 パルスを出力する場合を示しており， $\mathrm{NC} 2$ 曲線の S曲線（変位曲線）をディジタル化 し，これを 0,1 のビット列に直してメモリに記憶 している.これを Sテーブルと言っている.

実際にはこのSテーブルは出力 900 パルスに対 して作ってあり（これをクリティカルパルスと言 っている)，ストロークがこれより大きいときに は間に等速部を入れ，小さいときにはDDA (Digital Differential Analyzer) によって比例的 に下げて制御する（図 8 ). $\theta_{1}$ と $\theta_{2}$ の間でもPTP 制御でありながら DDA による補間を行っている ので，なめらかな動きを得ている.

実際のアームの動きを測定した一例を図 9 に示 す. 加速度波形にはやや振動が見られるが，速度 波形(タコゼネ出力による)は NC2 によく追随し て打り，変位波形（非接触変位計による）には才 ーバシュートや残留振動が観察されない。

\section{8.ロボットのスピードの設計}

一般に自動機械などで速度仕栐を定める基準と

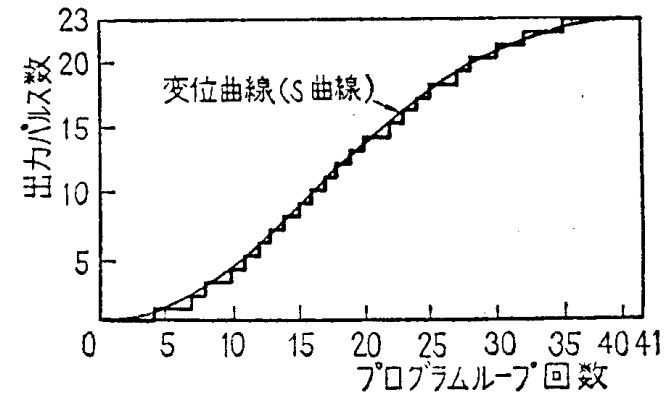

图 7 Sテーブル法

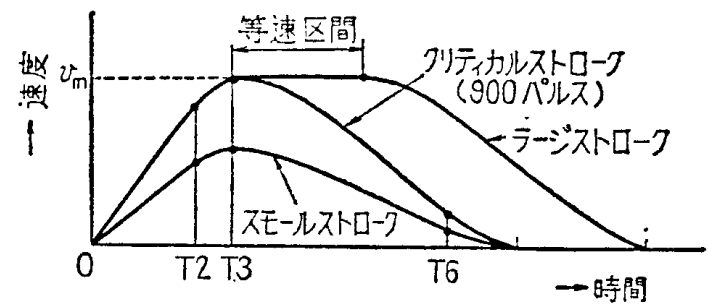

図 8 ラージストロークとスモールストローク
して表 2 のつの基準設定している.SCARA ロボットの場合, 当初俚人間並みのスピードで設 計した. 人間並みのスピードで人間並みのなめら かなカム曲線を用いれば，人間並みのふんわりと した動きを䒠現でき，柔らかいアームで重い物を 動かしても残留振動住起こらないはずなのであ る.この考えは実証されたが、 コンプライアンス の值が当初予想したよりも小さかったためさらに スピードを上げることができ，現在では表の機械 並みの数值に近ずきつつある。

いくつかの曲線について，与えられた速度限䀘 および加速度限界のもとで，ある距離を送るのに どれだけの時間を要するかを示したものが図 10 である。 その基礎式を下記に示す。

速度基準

$$
t_{h}=\frac{h \cdot V_{m}}{v_{m}}
$$

加速度基準

$$
t_{h}=\sqrt{\frac{h \cdot A_{m}}{a_{m}}}
$$

ただし，

$t_{h}$ : 搬送時間 $\mathrm{s}, h$ : 搬送距離 $\mathrm{mm}, v_{m}$ : 最大速 度 $\mathrm{mm} / \mathrm{s}, V_{m}$ : 力ム曲線の無次元最大速度, $a_{m}$ : 最大加速度 $\mathrm{mm} / \mathrm{s}^{2}, A_{m}$ ：力ム曲線の無次元最大 加速度

図を見ると， $1 \mathrm{~g}, 1 \mathrm{~m} / \mathrm{s}$ の人閒並みのスピード のもとで, NC2 曲線（場合によって等速部付き， 図 8 参照)を用いた場合， $200 \mathrm{~mm}$ を $0.35 \mathrm{~s}, 300$

\begin{tabular}{|c|c|c|}
\hline & $\underset{a_{m}}{\text { 聂大扣速㜊 }}$ & $\frac{\text { 聂 }}{v_{m}} \frac{\mathrm{m} / \mathrm{s}}{\mathrm{s}}$ \\
\hline 人閪 並 み & 1 & 1 \\
\hline 譏 珹 並 み & 3 & 2 \\
\hline 鬲速機械並み & 8 & 3 \\
\hline
\end{tabular}
表 2 速度限界基蕉

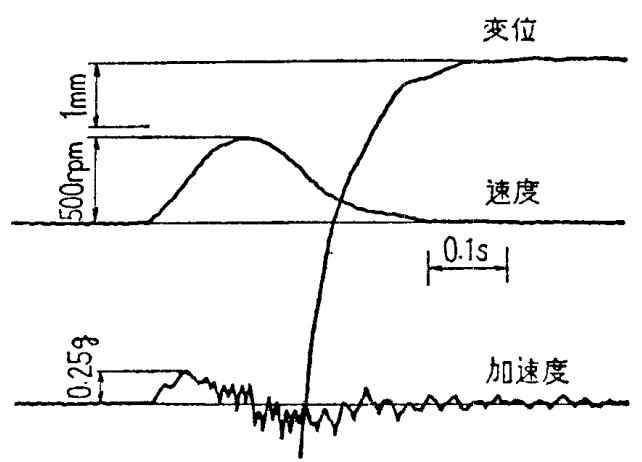

図 9 運動特性の一例 $\left(\theta_{2}\right.$ 軸単独動作， 320 パルス) 
$\mathrm{mm}$ を $0.45 \mathrm{~s}$ で送ることができることが分かる。 これは最短時間解を与える台形速度曲線（図示 TV)よりもごくわずか長いだけである。

このことから，たいていの組立作業は，人間並 みのなめらかな動きを用いて む，往復で $0.7 〜$ $0.9 \mathrm{~s}$ ，これに工具の上下とチャックの開閉を加え てもサイクルタイム $2 \sim 3 \mathrm{~s}$ で達成でることが 分かるであるう。事実この数值は現時点における スカラ形ロボットの平均的な数做となっている。

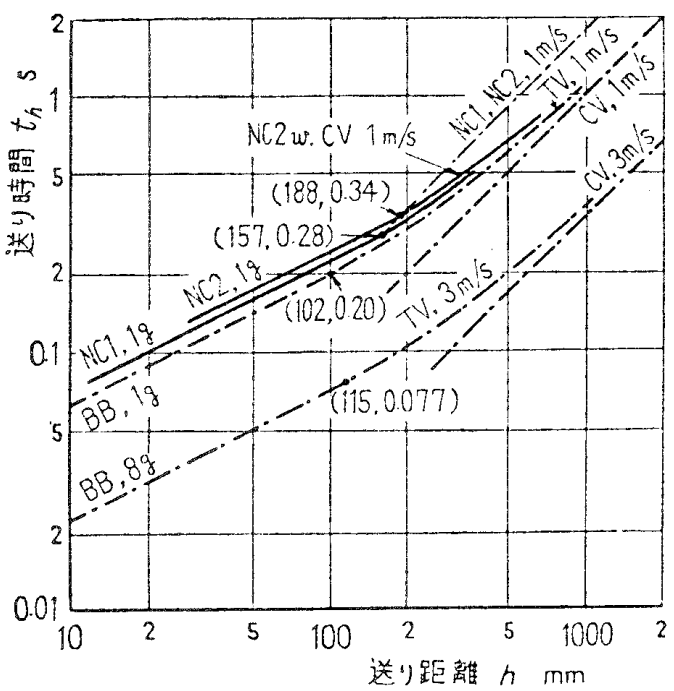

B B : Bang-Bang。三利速度波形，一定加做速 C V : Constant Velocity, 一走琲度 TV : Trapezoidal Velocity, 台形速度 $\mathrm{NC} 1: \mathrm{NC} 1$ 佃綵

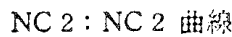
$\mathrm{NC} 2 \mathrm{w} . \mathrm{CV}:$ 等速部和告 $\mathrm{NC} 2$ 明線 图 10 各種の击線に执ける送り距滩と送り 時修の閔係

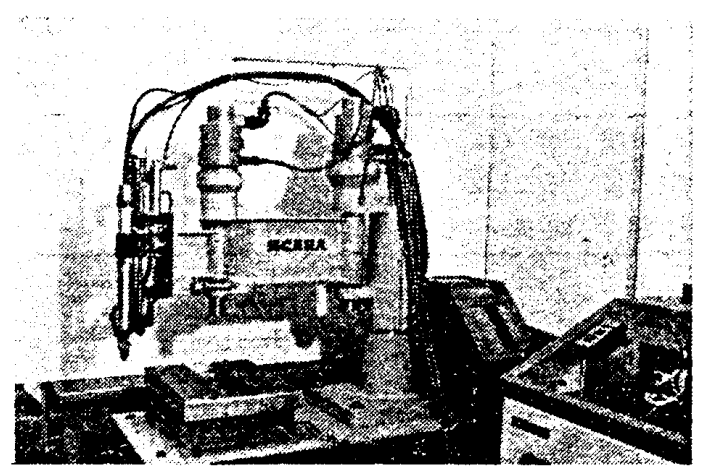

欧 11 SCARA ロボット（2卧㙨に孙し 維め工具在村けたとこる)

\section{9. 分解能の問題}

NC 工作機械の場合にはツールの精度とその㞄 動の精度がワークの精度を左右し，したがって分 解能が $0.01 \mathrm{~mm}$ からミクロンオーダへと進んで きたのであるが，組立機械の場合にはワークか゚先 に出来ており，これにツールを合わせるのである から，そんなに高い位置決め精度は必要でなく， せいぜい $0.2 \mathrm{~mm}$ も市れば十分なのである。その 代わり，コンプライアンスの効果がなければなら ない。

分解能を $0.01 \mathrm{~mm}$ として, 最高速度を $1 \mathrm{~m} / \mathrm{s}$ とすると最大周波数 $100 \mathrm{kHz}$ のパルスを出さな ければならない。これを $0.1 \mathrm{~mm}$ にすれば 10 $\mathrm{kHz}$ でよく，一つのパルスを出してから次のパル スを出すまでに $100 \mu \mathrm{s}$ の「考える時間」が与え ら机て，ソフトウェアによるカム曲線制御などが 可能になるのである。

\section{0．結言}

こうして出来たSCARA ロボットの外観を図 11 に示す。このロボットはその後数社から製品化さ れ，組立用ロボットの主流となりつつある．推定 の数字であるが 56 年までに約 500 台， 57 年には 約 2000 台が作られ稼動していると思われる.

（原稿受付 昭和 57 年 11 月 15 日)

文献

（1）牧野，楼椤教（第 538 回），(昭 57-6)，29.

(2) 牧野, 機誌, 81-721 (昭 53)，1237。

(3) 牧野, 粗管機㳦, 41-3 (昭 50)，250.

(4) Goto, T., 佂 2 名, Proc. 4th ISIR, Tokyo, (1974) 209.

(5) Whitney, D.E. and Nevins, J.L., Proc. 9th ISIR, Washington, (1979), 135.

（6）牧野・ほか2 名，精密機械，48-3（昭 57），378.

（7）䊑機等会自動組立索門委員会，䊑密譏械，39-4（昭 48）, 413.

（8）㧕，䒚金分虽，(昭 40)，美術出版社.

（9）仲野，䊑機学会自動組立専門委員会研究例会舜演前唰集 82-5 (昭 57)，1。

（10）牧野，自動機械機㩲学，（昭 51），日刊工業新聞社。

（11）牧野，山梨大学工学部研究報告，20 (昭 44)，41. 